\title{
Keterlibatan Notaris Dalam Pemberantasan Money Laundering Berdasarkan PP No. 43 Tahun 2015 Dikaitkan Dengan Asas Kerahasiaan Terbatas
}

\author{
Aganita Dhaneswara \\ Program Pascasarjana Fakultas Hukum Universitas Islam Indonesia \\ Jln. Cik Di Tiro No. 1, Yogyakarta, 55223 \\ aganitadhaneswara07@gmail.com
}

\begin{abstract}
In carrying out their duties and offices, a notary must always be guided by the Law on Public Notary (UUJN). In the UUJN, notaries are obliged to keep confidential everything concerning the deed they have produced and all information obtained for formulating the deed in accordance with the oath of office, unless the law stipulates otherwise. The obligation of notaries to report suspicious transactions is stated in Government Regulation (PP) No. 43 of 2015 on Reporting Parties in the Prevention and Eradication of Money Laundering, instead of by legislationg. Hence, this study intends to examine: first, whether the mention of a notary in the PP does not violate the principle of limited confidentiality; and second, whether the mention of a notary in the PP does not harm the notary. This is a normative legal research with qualitative descriptive analysis. The results of the study concluded that the obligation of notaries to report suspicious transactions caused debate among notaries and the Financial Transaction Reports and Analysis Center (PPATK). In theory, this obligation violates the principle of limited confidentiality, but if it is seen in the Money Laundering Law, the provisions of confidentiality can be excluded. This obligation does not cause harm to the notary because the notary as a witness and the reporting party is given protection by the state as regulated in the Money Laundering Law.
\end{abstract}

Key words: Limited confidentiality principle; money laundering; notary; witness

\begin{abstract}
Abstrak
Notaris dalam melaksanakan tugas dan jabatanya harus senantiasa berpedoman kepada UndangUndang Jabatan Notaris (UUJN). Dalam UUJN, notaris diwajibkan untuk merahasiakan segala sesuatu mengenai akta yang dibuatnya dan segala keterangan yang diperoleh guna pembuatan akta sesuai dengan sumpah jabatan, kecuali undang-undang menentukan lain. Kewajiban notaris melaporkan transaksi yang mencurigakan tertuang didalam PP No. 43 Tahun 2015 tentang Pihak Pelapor dalam Pencegahan dan Pemberantasan TPPU, bukan diatur oleh UU. Berdasarkan uraian tersebut, penelitian ini bermaksud mengkaji: pertama, apakah penyebutan notaris dalam PP tidak melanggar asas kerahasiaan terbatas; dan kedua, apakah penyebutan notaris dalam PP tersebut tidak merugikan notaris. Penelitian ini merupakan penelitian hukum normatif dengan analisis deskriptif kualitatif. Hasil penelitian menyimpulkan bahwa kewajiban notaris melaporkan transaksi yang mencurigakan menyebabkan perdebatan di kalangan notaris dan Pusat Pelaporan dan Analisis Transaksi Keuangan (PPATK). Secara teori kewajiban tersebut melanggar asas kerahasiaan terbatas, tetapi jika dilihat dalam UU Money Laundering, ketentuan kerahasiaan dapat dikecualikan. Kewajiban tersebut tidak menyebabkan kerugian untuk notaris dikarenakan notaris sebagai saksi dan pihak pelapor diberikan perlindungan oleh negara sebagaimana diatur dalam UU Money Laundering.
\end{abstract}

Kata-kata Kunci: Asas kerahasiaan terbatas; Notaris; saksi; money laundering 


\section{Pendahuluan}

Profesi notaris telah lama dikenal di Indonesia, bahkan jauh sebelum Indonesia merdeka yaitu pada masa pemerintah kolonial Belanda.Pada awalnya, keberadaan notaris merupakan suatu kebutuhan bangsa Eropa di Indonesia dalam upaya untuk menciptakan akta otentik.Keberadaan notaris makin dibutuhkan dalam membuat suatu alat bukti tertulis yang bersifat otentik dari suatu perbuatan hukum yang dilakukan masyarakat.Beberapa peraturan perundangan mewajibkan perbuatan hukum tertentu dibuat dalam akta otentik.Notaris dan produk aktanya dapat dimaknai sebagai upaya negara untuk menciptakan kepastian dan perlindungan hukum bagi anggota masyarakat. ${ }^{1}$

Hukum positif di Indonesia telah mengatur jabatan notaris dalam suatu undang-undang khusus.Pemerintah bersama dengan Dewan Perwakilan Rakyat menetapkan Undang-Undang Nomor 2 Tahun 2014 tentang Perubahan Atas Undang-Undang Nomor 30 Tahun 2004 tentang Jabatan Notaris.Merujuk pada Undang-Undang Jabatan Notaris Nomor 2 Tahun 2014 Pasal 1 menyatakan bahwa:2 notaris adalah pejabat umum yang berwenang untuk membuat akta otentik dan kewenangan lainnya. Notaris dikualifikasikan sebagai Pejabat Umum. Pejabat umum adalah orang yang menjalankan sebagian fungsi publik dari negara, khususnya di bidang hukum perdata.Pejabat umum adalah seorang yang diangkat dan diberhentikan oleh pemerintah dan diberi wewenang dan kewajiban untuk melayani publik dalam hal-hal tertentu karena ikut serta melaksanakan suatu kekuasaan yang bersumber pada kewibawaan dari pemerintah. ${ }^{3}$

Ciri yang dapat membedakan bahwa notaris adalah pejabat umum, yaitu, pertama, bahwa akta yang dibuat dihadapan/oleh Notaris mempunyai kekuatan sebagai alat bukti yang sempurna dan kuat serta mempunyai daya eksekusi. Akta Notaris seperti ini harus dilihat "apa adanya", sehingga jika ada pihak yang berkeberatan dengan akta tersebut, maka pihak yang berkeberatan, berkewajiban untuk membuktikanya.Ciri kedua,bahwa Notaris merupakan pejabat umum adalah notaris menerima tugasnya dari negara dalam bentuk delegasi dari negara.Ciri ketiga, bahwa Notaris di Indonesia (sebelumnya) diatur oleh Peraturan Jabatan Notaris (Reglement op het Notarisambt), Stb, 1860-3. Dalam teks asli disebutkan bahwa "ambt" adalah "jabatan", dalam Undang-Undang Nomor 2 Tahun 2014 tentang Perubahan Atas Undang-Undang Nomor 30 Tahun 2004 tentang Jabatan Notarisyang berarti mengatur hal-hal yang berkaitan dengan

${ }^{1}$ Hartanti Sulihandari dan Nisya Rifiani, Prinsip-Prinsip Dasar Profesi Notaris Berdasarkan Peraturan PerundangUndangan Terbaru, Cetakan Pertama, Dunia Cerdas, Jakarta 2013, hlm. 2-3.

2 Lihat Pasal 1 Undang-Undang Nomor 2 Tahun 2014 tentang Jabatan Notaris.

${ }^{3}$ Ibid. 
pelaksanaan Jabatan Notaris. Jadi tidak mungkin "ambt" yang berarti "jabatan" harus berubah menjadi profesi. ${ }^{4}$

Notaris merupakan pejabat umum yang mempunyai kewenangan dalam pembuatan akta otentik.Dalam melaksanakan jabatanya notaris mempunyai tanggungjawab moral terhadap jabatanya. Pelanggaran terhadap jabatan notaris pada akhirnya akan menimbulkan pertanggungjawaban bagi pengemban jabatan, baik itu bertanggungjawab secara administrasi maupun mengganti kerugian secara perdata, lebih jauh lagi notaris dapat bertanggungjawab secara pidana apabia seorang notaris melanggar Kitab Undang-Undang Hukum Pidana dalam melaksanakan tugas dan jabatanya. ${ }^{5}$ Pertanggungjawaban adalah keadaan wajib menanggung segala sesuatunya (kalau ada hal yang boleh dituntut dipersalahkan dan sebagainya). ${ }^{6}$

Seiring perkembangan zaman serta laju pertumbuhan ekonomi, berbagai macam transaksi keuangan juga mengalami perkembangan dan peningkatan, berbagai transaksi bisnis yang melibatkan Notaris juga semakin bervariasi, hal ini disebabkan oleh kebutuhan para pelaku bisnis atau pihak-pihak yang berkepentingan terhadap alat bukti tertulis yang bersifat otentik. Namun, bagaikan 2 sisi mata uang, tidak semua pihak yang datang menghadap kepada Notaris adalah untuk melakukan suatu transaksi yang bersih, ada juga pihakpihak yang datang dengan itikad buruk yang terselubung untuk melakukan suatu transaksi keuangan yang sejatinya melanggar hukum dengan tujuan mendapatkan perlindungan dibalik ketentuan kerahasiaan profesi Notaris sebagaimana diatur dengan ketentuan peraturan perundang-undangan sehingga transaksi yang dilakukannya terkesan bersih. Salah satu bentuk kejahatan tersebut adalah tindak pidana pencucian uang.

Menurut Farkhan Alisyahdi yang berprofesi sebagai jaksa, dalam acara konferwil Ikatan Notaris Indonesia (INI) Jawa Timur pada Senin 17 Oktober 2016 di Gedung Dyandra Convention Center Surabaya, notaris tidak hanya rentan terkena tindak pidana korupsi, tetapi notaris rentan juga dengan tindak pidana money laundering. Banyak notaris yang membantu transaksi korupsi dari pejabat negara.Pejabat negara yang terlibat korupsi meminta notaris mengurus suratsurat pembelian tanah, rumah dan apartment. Pada saat revisi Undang-Undang Nomor 8 Tahun 2010 tentang Pencegahan dan Pemberantasan Tindak Pidana

${ }^{4}$ Habib Adjie, Hukum Notaris Indonesia Tafsir Tematik. Terbadap UU No. 30 Tabun 2004 Tentang Jabatan Notaris, Cetakan Pertama, PT Rafika Aditama, Bandung, 2008, hlm. 9.

${ }^{5}$ M. Luthfan Hadi Daurus, Hukum Notariat Dan Tanggungjawab Jabatan Notaris, Cetakan Pertama, UII Press Yogyakarta, Yogyakarta , 2017, hlm. 49.

6 W. J. S Poerwadarminta, Kamus Bahasa Indonesia, Balai Pustaka, Jakarta, 1982, hlm. 1014. 
Pencucian Uang, terdapat pendapat yang menyatakan mengenai kewajiban notaris melaporkan transaksi yang dianggap mencurigakan atau tidak wajar dari klienya. Tetapi pada saat itu pihak organisasi Ikatan Notaris Indonesia yang disebut INI tidak setuju akan pendapat tersebut. ${ }^{7}$

Dalam pengertian sederhana, pencucian uang bisa dijelaskan sebagai tindakan "mengubah uang kotor menjadi uang bersih ". Satu ciri yang lazim dalam pendefinisian pencucian uang adalah "pengalihan asset ilegal ke dalam sistem ekonomi". ${ }^{9}$ Definisi lain dari pencucian uang dikemukakan oleh Pamela H. Bucy yang mengatakan bahwa pengertian pencucian uang adalah penyembunyian keberadaan, sifat atau sumber ilegal, pergerakan atau kepemilikan uang demi alasan apapun dengan tujuan melegalkan uang tersebut. ${ }^{10}$

Dalam bagian penjelasan Peraturan Pemerintah Republik Indonesia 43 Tahun 2015 tentang Pihak Pelapor Dalam Pencegahan dan Pemberantasan Tindak Pidana Pencucian Uang (selanjutnya dalam karya tulis ini disebut dengan PP No. 43 Tahun 2015 tentang Pihak Pelapor PPTPPU) disebutkan bahwa Tindak pidana pencucian uang merupakan tindak pidana yang dilakukan oleh pelaku dengan berusaha menyembunyikan atau menyamarkan asal usul harta kekayaan yang merupakan hasil dari tindak pidana dengan berbagai cara agar harta kekayaan hasil tindak pidananya sulit untuk ditelusuri oleh penegak hukum. Tindak pidana pencucian uang tersebut tidak hanya mengancam stabilitas dan integritas sistem keuangan serta sistem perekonomian negara tetapi juga dapat membahayakan sendi-sendi kehidupan berbangsa dan bernegara itusendiri.

Di Dalam Pasal 17 ayat (1) UU Pencucian Uang mengatur mengenai pihakpihak yang diwajibkan untuk menyampaikan laporan terhadap suatu transaksi yang terindikasi tindak pidana pencucian uang kepada Pusat Pelaporan dan Analisis Transaksi Keuangan (PPATK) yang selanjutnya disebut sebagai Pihak Pelapor. Pihak Pelapor tersebut meliputi:

1. Penyedia Jasa Keuangan, meliputi:
a. Bank;
b. PerusahaanPembiayaan;
c. Perusahaan Asuransi dan Perusahaan PialangAsuransi;
d. Dana Pensiun Lembaga Keuangan;

7 Didik Farhan, "Mungkinkah Notaris Korupsi?", http://didikfarkhan.com/index.php/catat/116mungkinkah-notaris-korupsi, diakses tanggal 2 Februari 2019.

${ }^{8}$ Rick McDonell, "Money Laundering Methodologies and International and Regional Countermeasures", dikutip dari Hanafi Amrani, Hukum Pidana Pencucian Uang, UII Press, Yogyakarta, 2015, hlm. 5.

${ }_{9}^{9}$ Febby Sekarini, "Sistem Pembuktian Dalam Perkara Gratifikasi Dan Pencucian Uang", Skripsi, Fakultas Hukum Universitas Islam Indonesia, Yogyakarta, 2018, hlm. 9.

${ }^{10}$ Ivan Yustiavandana, Arman Nefi dan Adiwarman, Tindak Pidana Pencucian Uang di Pasar Modal, Ghalia Indonesia, Bogor, 2010, hlm. 11. 

e. Perusahaan Efek;
f. Manajer Investasi;
g. Kustodian;
h. Wali Amanat;
i. Perposan sebagai Penyedia Jasa Giro;
j. Pedagang Valuta Asing;
k. Penyelenggara alat pembayaran menggunakan kartu;
1. Penyelenggara e-money dan/atau e-wallet;
m. Koperasi yang melakukan kegiatan simpan pinjam;
n. Pegadaian;
o. Perusahaan yang bergerak di bidang perdagangan berjangka komoditi; atau
p. Penyelenggara kegiatan usaha pengiriman uang.

2. Penyedia Barang dan/jasa lain, meliputi:

a. Perusahaan properti / agenproperti;

b. Pedagang kendaraan bermotor;

c. Pedagang permata dan perhiasan / logam mulia;

d. Pedagang barang seni dan antik; atau

e. Balai Lelang.

Sebagaimana yang telah disebutkan diatas, tindak pidana pencucian uang mengalami perkembangan khususnya dari cara kerjanya yang memanfaatkan pejabat-pejabat publik untuk melancarkan aksi kejahatannya maka, untuk menyikapi hal tersebut dibentuklah PP No. 43 Tahun 2015 tentang Pihak Pelapor PPTPPU yang secara khusus mengatur mengenai siapa saja yang dikategorikan sebagai Pihak Pelapor baru guna mencegah dan memberantas tindak pidana pencucian uang.

Berdasarkan Pasal 1 angka (3) PP No. 43 Tahun 2015 tentang Pihak Pelapor PPTPPU, yang dimaksud dengan Pihak Pelapor adalah setiap orang yang menurut peraturan perundang-undangan yang mengatur mengenai pencegahan dan pemberantasan tindak pidana pencucian uang wajib menyampaikan laporan kepada Pusat Pelaporan dan Analisis Transaksi Keuangan (PPATK).

Adapun substansi tambahan mengenai siapa saja yang dikategorikan sebagai Pihak Pelapor dalam PP No. 43 Tahun 2015 tentang Pihak Pelapor PPTPPU tersebut dimuat dalam Pasal 2 ayat (2) serta Pasal 3, yaitu:

1. Pasal 2 ayat (2) : Pihak Pelapor penyedia jasa keuangan selain sebagaimana dimaksud pada ayat (1) huruf (a) mencakup juga :
a. Perusahaan Modal Ventura;
b. Perusahaan Pembiayaan Infrastruktur;
c. Lembaga Keuangan Mikro; dan 
d. Lembaga Pembiayaan Ekspor.

2. Pasal 3 : Pihak Pelapor selain sebagaimana dimaksud dalam Pasal 2 mencakup juga :
a. Advokat;
b. Notaris;
c. Pejabat Pembuat AktaTanah;
d. Akuntan;
e. Akuntan Publik; dan
f. Perencana Keuangan.

Dalam bagian penjelasan PP No. 43 Tahun 2015 tentang Pihak Pelapor PPTPPU disebutkan juga maksud dan tujuan (ratio-legis) dari penambahan Pihak Pelapor yaitu :

1. Bagi penyedia jasa keuangan yang terdiri atas perusahaan modal ventura, perusahaan pembiayaan infrastruktur, lembaga keuangan mikro, dan lembaga pembiayaan ekspor sebagai Pihak Pelapor dilatarbelakangi oleh aktivitas bisnis atau usaha yang dilakukan oleh perusahaan atau lembaga tersebut rentan untuk dijadikan sarana dan sasaran tindak pidana pencucian uang.

2. Bagi advokat, notaris, pejabat pembuat akta tanah, akuntan, akuntan publik dan perencana keuangan yang berdasarkan hasil riset PPATK rentan dimanfaatkan oleh pelaku tindak pidana pencucian uang untuk menyembunyikan atau menyamarkan asal usul harta kekayaan yang merupakan hasil dari tindak pidana dengan cara berlindung dibalik ketentuan kerahasiaan hubungan profesi dengan Pengguna Jasa yang diatur sesuai dengan ketentuan peraturanperundang-undangan.

Penambahan Pihak Pelapor tersebut sejalan dengan rekomendasi yang dikeluarkan oleh Financial Action Task Force (FATF) yang menyatakan bahwa terhadap profesi tertentu yang melakukan Transaksi Keuangan Mencurigakan untuk kepentingan atau untuk dan atas nama Pengguna Jasa wajib melaporkan Transaksi tersebut kepada Financial Intelligence Unit (dalam hal ini adalah PPATK). Kewajiban pelaporan oleh profesi tersebut telah diterapkan di banyak negara dan memiliki dampak positif terhadap pencegahan dan pemberantasan tindak pidana pencucian uang.Selain itu, pengaturan Pihak Pelapor dan pelaksanaan kewajiban pelaporan oleh para Pihak Pelapor tersebut dimaksudkanuntuk melindungi mereka dari tuntutan hukum, baik secara perdata maupun pidana.

Berdasarkan permasalahan diatas, menurut penulis permasalahan tersebut diharuskan dikaji lebih mendalam untuk melihat apakah keterlibatan notaris dalam pemberantasan tindak pidana money laundering dengan kewajibanya melaporkan transaksi yang dianggap mencurigakan tidak melanggar asas kerahasiaan terbatas, dimana dalam Pasal 16 huruf f Undang-Undang Jabatan 
Notaris, notaris diwajibkan untuk merahasiakan segala sesuatu mengenai akta yang dibuatnya dan segala keterangan yang diperoleh guna pembuatan akta sesuai dengan sumpah/janji jabatan, kecuali undang-undang menentukan lain. Kewajiban notaris melaporkan transaksi yang mencurigakan tertuang didalam Peraturan Pemerintah Nomor 43 Tahun 2015 tentang Pihak Pelapor dalam Pencegahan dan Pemberantasan Tindak Pidana Pencucian Uang, bukan diatur oleh Undang-Undang.

\section{Rumusan Masalah}

Berdasarkan uraian tersebut di atas, maka rumusan masalah dalam penelitian hukum ini adalah sebagai berikut: Prertama, apakah kewajiban notaris melaporkan transaksi keuangan yang mencurigakan sesuai dengan Peraturan Pemerintah Nomor 43 Tahun 2015 tentang Pihak Pelapor dalam Pencegahan dan Pemberantasan Tindak Pidana Pencucian Uang tidak melanggar asas kerahasiaan terbatas Notaris? Kedua, apakah dimasukannya notaris dalam Peraturan Pemerintah Nomor 43 Tahun 2015 tentang Pihak Pelapor dalam Pencegahan dan Pemberantasan Tindak Pidana Pencucian Uang tidak merugikan notaris?

\section{Tujuan Penelitian}

Penelitian ini bertujuan untuk: pertama, mengidentifikasikan apakah kewajiban notaris melaporkan transaksi yang dianggap mencurigakan sesuai dengan Peraturan Pemerintah Nomor 43 Tahun 2015 tentang Pihak Pelapor dalam Pencegahan dan Pemberantasan Tindak Pidana Pencucian Uang tidak melanggar asas kerahasiaan terbatas notaris. Kedua, mengidentifikasikan apakah dimasukannya notaris dalam Peraturan Pemerintah Nomor 43 Tahun 2015 tentang Pihak Pelapor dalam Pencegahan dan Pemberantasan Tindak Pidana Pencucian Uang tidak merugikan notaris.

\section{Metode Penelitian}

\section{Jenis Penelitian}

Penelitian ini termasuk ke dalam penelitian hukum normatif. Penelitian ini adalah penelitian terhadap hukum positif yang terkait dengan Peraturan Pemerintah Nomor 43 Tahun 2015 dan kewajiban notaris dalam menjalankan tugas jabatanya. 


\section{Pendekatan Penelitian}

Metode pendekatan yang digunakan dalam penelitian ini adalah pendekatam perundang undangan dan konseptual. Pendekatan perundangundangan digunakan untuk mengkaji hierarki perundang-undangan dan semua perundang-undangan tentang jabatan notaris serta kode etik notaris.

\section{Fokus Penelitian}

Penelitian ini difokuskan untuk mengidentifikasikan apakah kewajiban notaris melaporkan transaksi yang dianggap mencurigakan sesuai dengan Peraturan Pemerintah Nomor 43 Tahun 2015 tentang Pihak Pelapor dalam Pencegahan dan Pemberantasan Tindak Pidana Pencucian Uang tidak melanggar asas kerahasiaan terbatas notaris.

\section{Sumber Data}

a. Data Primer

Yaitu data yang diperoleh langsung di lapangan, data primer dalam penulisan ini berupa informasi terhadap dan informasi terhadap Peraturan Pemerintah Nomor 43 Tahun 2015 dan kewajiban notaris dalam menjalankan jabatanya.

\section{b. Data Sekunder}

Yaitu data yang diperoleh dari bahan pustaka dan terdiri dari : penjelasan terhadap data primer yang berasal dari berbagai literatur.

\section{Bahan Hukum}

Yaitu bahan-bahan hukum yang mengikat khususnya dibidang Kenotariatan. a. Bahan hukum primer yang dipergunakan yaitu Peraturan Perundang-Undangan yang mempunyai relevansi dengan judul yang penulis akan teliti dan peraturan lain yang menunjang kelengkapan penelitian. b. Bahan hukum sekunder, yaitu bahan hukum yang memberikan informasi yang berkaitan dengan isi bahan hukum primer serta implementasinya. c. Bahan hukum tersier, yaitu bahan hukum yang memberi petunjuk maupun penjelasan terhadap bahan hukum primer dan bahan hukum sekunder, seperti kamus.

\section{Metode Pengumpulan Bahan Hukum}

Ada dua metode yang digunakan dalam pengumpulan bahan hukum, yaitu studi pustaka dan wawancara kepada notaris dan PPATK. Studi pustaka berupa penelusuran dan penelaahan literatur-literatur terkait dengan kewajiban tugas Sedangkan wawancara berupa wawancara terpimpin kepada narasumber tentang rumusan masalah yang akan dibahas. 


\section{Analisis}

Analisis yang digunakan dalam penelitian ini adalah deskriptif kualitatif, yaitu dengan menjabarkan, menguraikan, dan menyusun secara sistematis sesuai dengan tujuan penelitian atau memaparkan keadaan obyek sebagaimana adanya, berdasarkan fakta-fakta aktual yang terjadi sekarang.

\section{Hasil Penelitian dan Pembahasan}

Kewajiban Notaris untuk Melaporkan Transaksi Keuangan yang Mencurigakan Berdasarkan PP No. 43 Tahun 2015 dengan Asas Kerahasiaan Terbatas Jabatan Notaris.

Notaris dalam menjalankan profesinya memberikan pelayanan kepada masyarakat sepatutnya bersikap sesuai aturan yang berlaku. Hal ini penting karena Notaris melaksanakan tugas jabatannya tidaklah semata-mata untuk kepentingan pribadi, melainkan juga untuk kepentingan masyarakat, serta mempunyai kewajiban untuk menjamin kebenaran dari akta-akta yang dibuatnya, meskipun akta notaris tidak menjamin pihak atau penghadap berkata benar tetapi yang di jamin oleh akta notaris para pihak benar berkata seperti yang dimuat dalam akta. Oleh karena itu, seorang Notaris dituntut lebih peka, jujur, adil dan transparan dalam pembuatan suatu akta agar menjamin semua pihak yang terkait langsung dalam pembuatan sebuah akta autentik.

Dalam melaksanakan tugas jabatannya seorang Notaris harus berpegang teguh kepada kode etik jabatan Notaris, karena tanpa itu, harkat dan martabat profesionalisme akan hilang dan tidak lagi mendapat kepercayaan dari masyarakat. Seperti yang diajarkan dalam Islam mengenai amanah, orang amanah adalah dapat dipercaya. Dapat dipercaya dapat diartikan sebagai keyakinan kepada orang (trustee) bahwa orang tersebut dapat melakukan tugas. Dapat dipercaya lebih pada aspek kognitif individu (trustor) kepada orang (trustee) berdasarkan pengalaman, informasi dan kualitas karakter individu.

Secara umum notaris wajib merahasiakan isi akta dan keterangan yang diperoleh dalam pembuatan akta notaris, kecuali diperintahkan oleh undangundang bahwa notaris tidak wajib merahasiakan dan memberikan keterangan yang diperlukan yang berkaitan dengan akta tersebut. Dengan demikian, batasanya hanya undang-undang yang dapat memerintahkan notaris untuk membuka rahasia isi akta dan keterangan atau pernyataan yang diketahui notaris yang berkaitan dengan pembuatan akta yang dimaksud.

Bahwa instrument untuk ingkar bagi notaris ditegaskan sebagai salah satu kewajiban notaris yang tersebut dalam Pasal 16 ayat (1) huruf e Undang-Undang 
Jabatan Notaris sehingga kewajiban ingkar untuk notaris melekat pada tugas jabatan notaris. Sebagai suatu kewajiban harus dilakukan, berbeda dengan hak ingkar, yang dapat dipergunakan atau tidak dipergunakan, tetapi kewajiban ingkar mutlak dilakukan dan dijalankan oleh notaris, kecuali undang-undang yang memerintahkan untuk menggugurkan kewajiban ingkar tersebut. ${ }^{11}$

Notaris tidak dibolehkan untuk memberikan kesaksian mengenai apa yang dimuat dalam aktanya. Bagi Notaris hak ingkar merupakan kewajiban karena apabila dilanggar, maka Notaris akan dikenakan sanksi menurut UndangUndang. ${ }^{12}$ Jika ternyata notaris sebagai saksi, tersangka, tergugat, ataupun dalam pemeriksaan oleh majelis pengawas notaris membuka rahasia dan memberikan keterangan atau pernyataan yang seharusnya wajib dirahasiakan, sedangkan undang-undang tidak memerintahkanya, maka atas pengaduan pihak yang merasa dirugikan kepada pihak yang berwajib dapat dikenakan sanksi administrasi berupa teguran lisan, teguran tertulis, pemberhentian sementara, pemberhentian dengan hormat atau pemberhentian dengan tidak hormat; sanksi perdata berupa ganti rugi, maupun sanksi pidana Pasal 322 ayat (1) dan (2) Kitab Undang-Undang Hukum Pidana, yaitu membongkar rahasia, padahal notaris berkewajiban untuk menyimpanya. Dalam kedudukan sebagai saksi (perkara perdata), notaris dapat minta dibebaskan dari kewajibanya untuk memberikan kesaksian karena jabatanya menurut undang-undang diwajibkan untuk merahasiakanya sesuai Pasal 1909 ayat (3) Kitab Undang-Undang Hukum Perdata.

Kewajiban ingkar yang harus dilakukan notaris berdasarkan Pasal 44 ayat (2) dan Pasal 16 ayat (1) huruf e Undang-Undang Jabatan Notaris dapat tidak dilaksanakan kecuali undang-undang undang-undang memerintahkanya untuk membuka rahasia dan memberikan keterangan atau pernyataan tersebut kepada pihak yang memintanya. Saat ini, undang-undang yang memerintahkan notaris untuk mengesampingkan kewajiban ingkar dijelaskan dalam Undang-Undang Nomor 8 Tahun 2010 tentang Pencegahan dan Pemberantasan Tindan Pidana Pencucian Uang melalui peraturan pelaksana yaitu PP Nomor 43 Tahun 2015 tentang Pihak Pelapor dalam Pencegahan dan Pemberantasan Tindak Pidana Pencucian Uang.

Peraturan Pemerintah Nomor 43 Tahun 2015 tentang Pihak Pelapor dalam Pencegahan dan Pemberantasan Tindak Pidana Pencucian Uang jika ditinjau dari teori asas kerahasiaan terbatas dapat dikatakan melanggar asas kerahasiaan

${ }^{11}$ Ibid.

12 Wawan Setiawan, Kedudukan Dan Keberadaan Pejabat Umum serta PPAT dibandingkan dengan Kedudukan Pejabat Tata Usaha Negara Menurut Sistem Hukum Nasional, Jakarta, 2001, hlm. 10. 
terbatas Notaris. ${ }^{13}$ Tetapi disisi lain disampaikan oleh Bapak Burhan, Notaris di Kulon Progo bahwa asas kerahasiaan terbatas dapat dikesampingkan dengan kepentingan publik karena tindak pidana pencucian merupakan kejahatan luar biasa. Dalam konteks tertentu kewajiban ingkar dapat dikesampingan demi kemaslahatan bersama, karena hal tersebut merupakan perintah negara. ${ }^{14}$ Pasal 28 Undang-Undang Nomor 8 Tahun 2010 tentang Pencegahan Dan Pemberantasan Tindak Pidana Pencucian Uang mengecualikan ketentuan kerahasiaan yang berlaku bagi Pihak Pelapor yang bersangkutan. Dikesampingkanya kewajiban ingkar diatur juga dalam Pasal 45 Undang-Undang Nomor 8 Tahun 2010 tentang Pencegahan Dan Pemberantasan Tindak Pidana Pencucian Uang. ${ }^{15}$ PPATK berpendapat disebutkanya Notaris didalam Peraturan Pemerintah Nomor 43 Tahun 2015 tentang Pihak Pelapor dalam Pencegahan dan Pemberantasan Tindak Pidana Pencucian Uang tidak melanggar asas kerahasiaan terbatas sesuai dengan Pasal 28 dan Pasal 45 Undang-Undang Nomor 8 Tahun 2010 tentang Pencegahan Dan Pemberantasan Tindak Pidana Pencucian Uang, dimana disebutkan bahwa kewajiban kerahasiaan dapat dikecualikan.

\section{Pencantuman Jabatan Notaris dalam PP No. 43 Tahun 2015 Tidak Merugikan Notaris}

Pencantuman Jabatan Notaris didalam PP Nomor 43 Tahun 2015 tentang Pihak Pelapor Pencegahan dan Pemberantasan Tindak Pidana Pencucian Uang tidak mudah dilakukan oleh Notaris. Meskipun telah dijelaskan indikator transaksi keuangan yang mencurigakan, penjelasan kewajiban notaris dalam melaporkan transaksi keuangan yang mencurigakan yang diatur oleh UndangUndang Nomor 8 Tahun 2010 tentang Pencegahan Dan Pemberantasan Tindak Pidana Pencucian Uang hal tersebut sulit dilakukan oleh notaris dikarenakan notaris merupakan jabatan kepercayaan. Menurut pendapat Muhammad Aji, Notaris di Kota Yogyakarta, bentuk perlindungan yang diberikan oleh negara masih tidak terlalu jelas.Notaris dapat dirugikan apabila disebutkan sebagai Pihak Pelapor tindak pidana pencucian uang dikarenakan Notaris merupakan jabatan kepercayaan. ${ }^{16}$ Jabatan notaris merupakan jabatan kepercayaan yang harus selaras dengan mereka yang menjalankan tugas jabatan notaris sebagai orang yang dipercaya. Notaris sebagai jabatan yang kepercayaan tidak berarti

\footnotetext{
${ }^{13}$ Hasil wawancara dengan Bapak Burhan, pada tanggal 8 Januari 2020, pada pukul 11.19 WIB.

${ }^{14}$ Ibid.

${ }^{15}$ Ibid.

${ }^{16}$ Hasil wawancara dengan Bapak Muhammad Aji, pada tanggal 15 Januari 2020, pada pukul 11.40 WIB.
} 
apa-apa jika ternyata mereka menjalankan tugas jabatan sebagai notaris adalah orang yang tidak dapat dipercaya. ${ }^{17}$

Fitrizki Utami ${ }^{18}$ menyatakan, bahwa adanya arus modernisasi dan globalisasi yang melanda Indonesia akan membawa lembaga-lembaga hukum baru di bidang perekonomian dan perdagangan. Notaris sebagai suatu profesi yang diangkat oleh negara untuk melaksanakan alat bukti berupa akta autentik, diharapkan selalu berpegang teguh dan menjunjung tinggi martabat profesinya sebagai profesi kepercayaan dan terhormat. ${ }^{19}$

Menurut sejarah profesinya maupun kenyataanya, notaris merupakan orang yang menjadi kepercayaan masyarakat, karena itu kedudukanya harus dijunjung tinggi. ${ }^{20}$ Untuk melindungi unsur kepercayaan masyarakat kepada notaris, sebagaimana profesi lainya bahwa notaris mempunyai kewajiban untuk merahasiakan informasi yang diperoleh dari klienya.Sebagai pengemban jabatan dan profesi kepercayaan, sebelum menjalankan jabatanya, notaris terlebih dahulu harus mengucapkan sumpah/janji.

Asas kepercayaan merupakan suatu asas yang menyatakan bahwa jabatan notaris dilandasi oleh hubungan kepercayaan antara notaris dengan klienya. Notaris terutama bekerja dan mendapatkan honorarium dari klienya yang menggunakan jasa notaris atas dasar kepercayaan, sehingga setiap notaris perlu terus menjaga amanah dengan tetap memelihara dan mempertahankan kepercayaan masyarakat kepadanya.Keinginan masyarakat untuk membuat akta otentik kepada notaris, semata-mata dilandasi oleh kepercayaan. Asas kepercayaan juga disebut legal expectation, harapan-harapan yang ditimbulkan (janji-janji, keterangan-keterangan, aturan-aturan kebijaksanaan dan rencana-rencana) sebisa mungkin harus dipenuhi. Dalam melaksanakan tugasnya membuat akta otentik, seorang notaris wajib menjalankan ketentuan dalam Undang-Undang Jabatan Notaris.Notaris diwajibkan untuk bertindak jujur, saksama, mandiri, tidak berpihak, dan menjaga kepentingan pihak yang terkait dalam perbuatan hukum.

Pelaporan transaksi keuangan yang mencurigakan yang dilakukan oleh notaris hanya sebatas berdasarkan perintah Undang-Undang Nomor 8 Tahun 2010 tentang Pencegahan Dan Pemberantasan Tindak Pidana Pencucian Uang melalui Peraturan Pemerintah Nomor 43 Tahun 2015 tentang Pihak Pelapor

${ }^{17}$ Habib Adjie (II), Sanksi Perdata dan Administratif Terbadap Notaris Sebagai Pejabat Publik, Bandung: Refika Aditama, 2009, hlm. 83.

18 Fitrizki Utami, "Penegakan Hukum Terhadap Tanggung Jawab Notaris Atas Pelaksanaan Tugas Pelayanan Publik (Law Enforcement on Notary's Responsibility in Providing Public Service)", Disertasi Pascasarjana Fakultas Hukum Universitas Hasanudin, Makasar, hlm. 6.

${ }^{19}$ Ghansham Anand, Karakteristik Jabatan Notaris Di Indonesia, Prenadamedia Group, Jakarta, 2018, hlm. 118. 
Pemberantasan dan Pencegahan Tindak Pidana Pencucian Uang. Atas tunduknya notaris terhadap perintah Undang-Undang Nomor 8 Tahun 2010 tentang Pencegahan Dan Pemberantasan Tindak Pidana Pencucian Uang notaris mendapatkan perlindungan sebagai pihak pelapor maupun saksi dari undangundang tersebut.

Meskipun notaris mendapatkan perlindungan sebagai pihak pelapor dan saksi dari undang-undang. Pencantuman jabatan notaris sebagai pihak pelapor menurut. Mulyoto dapat merugikan notaris dari segi pidana. ${ }^{21}$ Notaris beresiko dituduh melakukan pencemaran nama baik, apabila klien yang dilaporkan Notaris pada PPATK tidak terbukti melakukan tindak pidana pencucian uang. Kewajiban melaporkan akan membebani Notaris, dikarenakan kewajiban melaporkan merupakan pandangan subyektif dari Notaris. Notaris tidak mengetahui dari mana asal-usul uang klien, identitas lengkap klien tidak dapat diketahui sampai kebenaran materiil. Berbeda dengan pendapat PPATK, notaris tidak dapat dikenakan tuntutan pencemaran nama baik dikarenakan Pihak Pelapor dilindungi oleh Undang-Undang sesuai Pasal 29 Undang-Undang Nomor 8 Tahun 2010 tentang Pencegahan Dan Pemberantasan Tindak Pidana Pencucian Uang. ${ }^{22}$

Perlindungan yang diberikan oleh Undang-Undang dirasa kurang jelas dikarenakan peraturan mengenai perlindungan Notaris tidak lengkap dan tidak harmonis. Notaris Burhan melihat ketidakjelasan perlindungan sampai sejauh mana Pemerintah dapat melindungi Pihak Pelapor khususnya Notaris. ${ }^{23}$ UndangUndang Nomor 8 Tahun 2010 tentang Pencegahan Dan Pemberantasan Tindak Pidana Pencucian Uang menjelaskan perlindungan yang diberikan adalah perlindungan terkait identitas Pihak Pelapor dan semua yang terkait dengan Pihak Pelapor seperti informasi dan dokumen yang diberikan oleh Pihak Pelapor. ${ }^{24}$ Dalam perlindungan terhadap informasi dan dokumen, yang dijaga adalah informasi-informasi yang berhubungan dengan pencucian uang baik berupa informasi, keterangan, surat, identitas pihak pelapor, maupun dokumen. Perlindungan ini bukanlah untuk mencegah terjadinya pencucian uang, melainkan perlindungan terhadap proses perbuatan pembuktian informasi, keterangan, surat, dan dokumen yang dilakukan oleh para pelaksana undang-undang.

Perbuatan melindungi dari uraian tersebut adalah perbuatan yang mengharuskan kepada seseorang atau setiap orang untuk melakukan perbuatan

${ }^{21}$ Hasil wawancara dengan Dr. Mulyoto, pada tanggal 12 September 2019, pada pukul 11.20 WIB.

${ }^{22}$ Lihat Pasal 29 Undang-Undang Nomor 8 Tahun 2010 Tentang Pencegahan Dan Pemberantasan Tindak Pidana Pencucian Uang.

${ }^{23}$ Hasil wawancara dengan Bapak Burhan, pada tanggal 8 Januari 2020, pada pukul 11.19 WIB.

${ }^{24}$ Hasil wawancara dengan PPATK, pada tanggal 23 Januari 2020, pada pukul 10.26 WIB. 
merahasiakan tentang segala sesuatu informasi, keterangan, surat, dokumen perbuatan pidana yang diterima atau diberikan oleh setiap orang atau seseorang. Apabila melakukan perbuatan "tidak merahasiakan", ini bertentangan dengan kepentingan yang dilindungi. Kepentingan yang dilindungi adalah kepentingan hukum untuk pembuktian pencucian uang, apabila dilanggar merupakan perbuatan yang bertentangan dengan kepentingan yang dilindungi. 25 Pada prosesnya, informasi, dokumen atau keterangan ini akan mengalir, yaitu dari setiap orang kepada penyedia jasa keuangan, kemudian kepada pelaksana atau pejabat yang ditunjuk oleh undang-undang.

Dalam undang-undang, pelarangan atau wajib merahasiakan ini berlaku bagi siapa pun, jangan sampai diberitakan kepada masyarakat atau diberitahukan kepada masyarakat umum, siapa pun itu. Dalam undang-undang tindak pidana pencucian uang dirumuskan yang dilindungi adalah "pelapor atau saksi" dengan demikian perlindungan terhadap subjek perbuatan adalah terhadap pelapor atau saksi yang melakukan perbuatan melaporkan mengetahui atau menduga harta kekayaan yang berasal dari hasil tindak pidana.

Dengan adanya ketentuan dalam undang-undang tersebut, pelapor mempunyai kewajiban menyampaikan laporan, dan yang mewajibkanya adalah undang-undang. Oleh karena itu, apabila terdapat perlawanan atau tuntutan balik karena pelaporan itu, undang-undang harus melindungi. Sebab, pelapor telah melakukan suatu perbuatan untuk undang-undang. Bentuk perlindungan undang-undang terhadap pelapor atau saksi dapat dilihat pada ketentuan Pasal 87 dan Pasal 84 Undang-Undang Nomor 8 Tahun 20101 tentang Pencegahan dan Pemberantasan Tindak Pidana Pencucian Uang.

Pasal 87 Undang-Undang Nomor 8 Tahun 20101 tentang Pencegahan dan Pemberantasan Tindak Pidana Pencucian Uang berbunyi: "Pelapor dan atau saksi tidak dapat dituntut baik secara perdata atau pidana atas laporan dan atau kesaksian yang diberikan oleh yang bersangkutan".

Tuntutan balik atau perlawanan balik merupakan suatu perbuatan yang dilakukan sesuai dengan aturan hukum, tetapi belum tentu semua perlawanan balik itu dilakukan dengan suatu perbuatan yang sesuai dengan aturan hukum, apabila perbuatan perlawanan balik itu dilakukan tidak menurut aturan hukum misalnya dengan cara kekerasan atau tekanan fisik ataupun nonfisik terhadap jiwa atau badan pelapor atau saksi, maka pelapor atau saksi tetap perlu dilindungi oleh hukum atau undang-undang.

25 Tubagus Irman, Money Laundering Hukum Pembuktian Tindak Pidana Pencucian Uang dalam Penetapan Tersangka, Gramedia Pustaka Utama, Jakarta, 2017, hlm. 191. 
Pasal 84 Undang-Undang Nomor 8 Tahun 20101 tentang Pencegahan dan Pemberantasan Tindak Pidana Pencucian Uang berbunyi: "Setiap orang yang melaporkan terjadinya dugaan tindak pidana pencucian uang wajib diberi perlindungan khusus oleh negara dari kemungkinan ancaman yang membahayakan diri, jiwa, dan atau/hartanya, termasuk keluarganya". Kemudian dipersiapkan juga apabila ternyata pelapor atau saksi dalam proses hukum harus menjadi saksi, dengan memberikan kesaksianya dalam pemeriksaan tindak pidana pencucian uang, ia tetap dilindungi oleh hukum sesuai Pasal 85 ayat (3) Undang-Undang Nomor 8 Tahun 2010 tentang Pencegahan dan Pemberantasan Tindak Pidana Pencucian Uang. ${ }^{26}$ "Setiap orang yang memberikan kesaksian dalam pemeriksaan tindak pidana pencucian uang wajib diberi perlindungan khusus oleh negara dari kemungkinan ancaman yang membahayakan diri, jiwa dan atau hartanya, termasuk keluarganya".

Perlindungan terhadap pelapor atau saksi karena melaporkan atau memberitahukan atau memberikan kesaksian dalam dugaan adanya tindak pidana pencuian uang, terdiri atas:

1. Perlindungan dari tuntutan perdata maupun pidana

2. Perlindungan dari ancaman yang membahayakan diri pelapor atau saksi

3. Pelapor atau saksi tidak dapat dituntut baik secara perdata atau pidana atas laporan dan atau kesaksian yang diberikan oleh yang bersangkutan

4. Setiap orang yang melaporkan terjadinya dugaan tindak pidana pencucian uang wajib diberi perlindungan khusus oleh negara dari kemungkinan ancaman yang membahayakan diri, jiwa, dan atau/ hartanya, termasuk keluarganya

5. Setiap orang yang memberikan kesaksian dalam pemeriksaan tindak pidana pencucian uang, wajib diberi perlindungan khusus oleh negara dari kemungkinan ancaman yang membahayakan diri, jiwa, dan atau/hartanya, termasuk keluarganya.

Notaris sebagai pihak pelapor apabila mengetahui adanya transaksi keuangan yang mencurigakan tetapi tidak melaporkan kepada PPATK sesuai Pasal 25 ayat (4) yang berbunyi: "Penyedia jasa keuangan yang tidak menyampaikan laporan kepada PPATK sebagaimana dimaksud pada ayat (1), ayat (2), dan ayat (3), dikenai sanksi administratif. Pengenaan sanksi administratif dilakukan oleh Lembaga Pengawas dan Pengatur sesuai dengan ketentuan peraturan perundang-undangan. Dalam hal lembaga pengawas dan pengatur belum terbentuk, pengenaan sanksi administratif terhadap pihak pelapor dilakukan oleh PPATK. Sanksi administratif yang dikenakan oleh PPATK dapat 
berupa: peringatan, teguran tertulis, pengumuman kepada publk mengenai tindakan atau sanksi dan/atau denda administratif.

\section{Penutup}

Berdasarkan uraian tersebut di atas, adapun yang dapat disimpulkan dari penelitian ini sebagai berikut: Pertama, notaris sebagai Pejabat Umum dalam menjalankan profesi dan jabatannya untuk memberikan pelayanan hukum kepada masyarakat, mempunyai kewajiban yang ditentukan dalam Undang-Undang demi tercapainya perlindungan dan kepastian hukum, antara lain: Pasal 4 ayat (2) UUJN dalam alinea ke 4 memuat Sumpah Jabatan Notaris mengenai kewajiban Notaris untuk merahasiakan isi akta: "...bahwa saya akan merahasiakan isi akta dan keterangan yang diperoleh dalam pelaksanaan jabatan saya...". Notaris wajib merahasiakan isi akta dan segala keterangan yang diperoleh dalam pelaksanaan jabatannya. Hal ini sejalan dengan sumpah jabatan yang diucapkan sebelum Notaris melaksanakan jabatannya, sebagaimana ditegaskan dalam Pasal 4 ayat (2) UUJN. Notaris tidak bisa secara bebas mengungkapkan atau membocorkan rahasia jabatannya kepada siapa pun kecuali terdapat peraturan perundang-undangan lain yang memperbolehkannya untuk membuka rahasia jabatannya. Sumpah jabatan tersebut ditegaskan sebagai salah satu kewajiban Notaris yang diatur dalam Pasal 16 ayat (1) huruf f, yang menyatakan dalam menjalankan jabatannya, Notaris berkewajiban merahasiakan segala sesuatu mengenai akta yang dibuatnya dan segala keterangan yang diperoleh guna pembuatan akta sesuai dengan sumpah/janji jabatan, kecuali undang- undang menentukan lain yang biasa disebut dengan asas kerahasiaan terbatas atau kewajiban ingkar. Pengertian terbatas mengandung pengertian apabila undang-undang menentukan lain. Undang-undang yang dimaksud saat ini Undang-Undang Nomor 8 Tahun 2010 tentang Pencegahan Dan Pemberantasan Tindak Pidana Pencucian Uang melalui PP Nomor 43 Tahun 2015 tentang Pihak Pelapor Pencegahan dan Pemberantasan Tindak Pidana Pencucian Uang yang mencantumkan jabatan notaris sebagai salah satu pihak pelapor. Pencantuman jabatan notaris secara teori melanggar asas kerahasiaan terbatas notaris dikarenakan pencantuman tersebut melalui Peraturan Pemerintah bukan undang-undang.Namun secara praktik asas kerahasiaan terbatas dapat dikesampingkan demi kemaslahatan masyarakat dan peraturan pemerintah tersebut merupakan peraturan pelaksana dari Undang-Undang Nomor 8 Tahun 2010 tentang Pencegahan Dan Pemberantasan Tindak Pidana Pencucian Uang. Pasal 28 UndangUndang Nomor 8 Tahun 2010 tentang Pencegahan Dan Pemberantasan Tindak Pidana Pencucian Uang mengecualikan ketentuan kerahasiaan yang berlaku bagi Pihak Pelapor yang bersangkutan. Dikesampingkanya Kewajiban ingkar tersebut 
diatur juga dalam Pasal 45 Undang-Undang Nomor 8 Tahun 2010 tentang Pencegahan Dan Pemberantasan Tindak Pidana Pencucian Uang.Pencantuman jabatan notaris sebagai Pihak Pelapor tidak melanggar asas kerahasiaan terbatas sesuai Pasal 28 dan Pasal 45 Undang-Undang Nomor 8 Tahun 2010 tentang Pencegahan Dan Pemberantasan Tindak Pidana Pencucian Uang.

Kedua, disebutkanya Notaris sebagai Pihak Pelapor dalam Peraturan Pemerintah Nomor 43 Tahun 2015 tidak merugikan Notaris, dikarenakan Notaris mendapatkan perlindungan dari negara sebagai pihak pelapor atau saksi atas tunduknya notaris terhadap perintah Undang-Undang Nomor 8 Tahun 2010 tentang Pencegahan Dan Pemberantasan Tindak Pidana Pencucian Uang. Undang-undang menjelaskan perlindungan yang diberikan adalah perlindungan terkait identitas Pihak Pelapor, pihak pelapor sebagai saksi dan semua yang terkait dengan Pihak Pelapor seperti informasi dan dokumen yang diberikan oleh Pihak Pelapor. Notaris sebagai pihak pelapor apabila mengetahui adanya transaksi keuangan yang mencurigakan tetapi tidak melaporkan kepada PPATK sesuai Pasal 25 ayat (4) yang berbunyi : "Penyedia jasa keuangan yang tidak menyampaikan laporan kepada PPATK sebagaimana dimaksud pada ayat (1), ayat (2), dan ayat (3), dikenai sanksi administratif.

Melalui tulisan ini, Penulis bermaksud memberikan saran sebagai berikut: Pertama, disebutkanya notaris sebagai pihak pelapor transaksi yang mencurigakan dapat tidak menimbulkan permasalahan apabila peraturan yang menyebutkanya diubah menjadi undang-undang tidak hanya Peraturan Pemerintah. Dalam membuat peraturan perundang-undangan seharusnya pemerintah lebih memperhatikan harmonisasi serta sinkronisasi undang-undang yang satu dengan undang-undang yang lainya. Kedua, perbedaan kepentingan dapat dihilangkan apabila pembentuk undang-undang dalam membuat peraturan lebih memberikan kepastian hukum kepada masyarakat. Mengajak masyarakat dalam pembahasan pembentukan peraturan agar selaras dengan kepentingan masyarakat. Harmonisasikan kepentingan PPATK dengan Notaris untuk membantu negara dalam pemberantasan dan pencegahan tindak pidana pencucian uang.

\section{Daftar Pustaka}

\section{Buku}

Adjie, Habib, Hukum Notaris Indonesia Tafsir Tematik Terhadap UU No. 30 Tahun 2004 Tentang Jabatan Notaris, Cetakan Pertama, PT Rafika Aditama, Bandung, 2008. 
Adjie, Habib, Sanksi Perdata dan Administratif Terhadap Notaris Sebagai Pejabat Publik, Refika Aditama, Bandung, 2009.

Anand, Ghansham, Karakteristik Jabatan Notaris Di Indonesia, Prenadamedia Group, Jakarta, 2018.

Daurus, M. Luthfan Hadi, Hukum Notariat Dan Tanggungjawab Jabatan Notaris, Cetakan Pertama, UII Press Yogyakarta, Yogyakarta, 2017.

Irman, Tubagus, Money Laundering Hukum Pembuktian Tindak Pidana Pencucian Uang dalam Penetapan Tersangka, Jakarta: PT. Gramedia Pustaka Utama, 2017.

McDonell, Rick, "Money Laundering Methodologies and International and Regional Countermeasures", dikutip dari Hanafi Amrani, Hukum Pidana Pencucian Uang, UII Press, Yogyakarta, 2015.

Poerwadarminta, W. J. S, Kamus Bahasa Indonesia, Balai Pustaka, Jakarta, 1982.

Rifani, Nisya dan Sulihandari Hartanti, Prinsip-Prinsip Dasar Profesi Notaris Berdasarkan Peraturan Perundang-Undangan Terbaru, Cetakan Pertama, Dunia Cerdas, Jakarta 2013.

Sekarini, Febby, Sistem Pembuktian Dalam Perkara Gratifikasi Dan Pencucian Uang, Skripsi, Fakultas Hukum Universitas Islam Indonesia, Yogyakarta, 2018.

Setiawan, Wawan, Kedudukan Dan Keberadaan Pejabat Umum serta PPAT dibandingkan dengan Kedudukan Pejabat Tata Usaha Negara Menurut Sistem Hukum Nasional, Jakarta, 2001.

Yustiavandana, Ivan, Arman Nefi dan Adiwarman, Tindak Pidana Pencucian Uang di Pasar Modal, Ghalia Indonesia, Bogor, 2010.

\section{Hasil Penelitian}

Utami, Fitrizki, "Penegakan Hukum Terhadap Tanggung Jawab Notaris Atas Pelaksanaan Tugas Pelayanan Publik (Law Enforcement On Notary's Responsibility In Providing Public Service), Disertasi, Pascasarjana Fakultas Hukum Universitas Hasanudin, Makasar.

\section{Internet}

Didik Farhan, "Mungkinkah Kotaris Korupsi?" http:/ / didikfarkhan.com/index.php/catat/116-mungkinkah-notariskorupsi, iakses pada tanggal 2 Februari 2019

\section{Peraturan Perundang-Undangan}

Undang-Undang Nomor 2 Tahun 2014 Tentang Perubahan Atas Undang-Undang Nomor 30 Tahun 2004 Tentang Jabatan Notaris.

Undang-Undang Nomor 8 Tahun 2010 Tentang Pencegahan Dan Pemberantasan Tindak Pidana Pencucian Uang.

Peraturan Pemerintah Nomor 43 Tahun 2015 Tentang Pihak Pelapor Pemberantasan dan Pencegahan Tindak Pidana Pencucian Uang. 